\title{
DOES ACUTE TRAMADOL TOXICITY INDUCE HYPOGLYCEMIA AND ACUTE PANCREATITIS? A CLINICAL STUDY OF ACUTE TRAMADOL POISONED PATIENTS
}

\author{
Eglal Hassan Elawady and Hind Mohamed Elhilaly \\ Forensic Medicine and Clinical Toxicology Department \\ Faculty of Medicine - Ain Shams University
}

\begin{abstract}
Tramadol is a centrally acting synthetic analgesic. Recently, tramadol overdose has become one of the most common causes of acute poisoning in Egypt and worldwide. Common symptoms of toxicity include respiratory depression and seizure. Hypoglycemia is another potentially fatal hazard that is newly emerging in association with tramadol. Therefore, the aim of this study is to investigate the effect of tramadol poisoning on blood glucose level and whether or not this effect is associated with tramadol-induced acute pancreatitis. Methods: A prospective study was conducted on patients admitted to the Poison Control Center, Ain Shams University hospitals from November 2014 to August 2016 with acute tramadol poisoning. All the patients were subjected to complete medical history, physical examination and routine biochemical laboratory tests. In addition to, measurement of serum levels of amylase, lipase and insulin. Blood glucose level was obtained twice; on admission and on the second day. Results: twenty nine patients, 25 males (86.2\%) and 4 females (13.79\%) met inclusion criteria. Mean age was $(31.34 \pm 8.75$ years $)$. There was significant decrease of blood pressure and respiratory rate in the tramadol poisoned patients (case group) as compared with the control group. The most frequent manifestations were; nausea and vomiting (93.1\%), abdominal pain (86.2\%), coma II (55.17\%), miosis $(37.93 \%)$ and sweating $(34.48 \%)$. There was significant decrease of $\mathrm{pH}, \mathrm{PO} 2$ and HCO3 and a significant increase of PCO2 in tramadol intoxicated patients. The case group showed significant decrease of glucose level on the second day as compared to the control group, as well as, when compared with glucose level on admission day. There was a significant increase of serum amylase level and a non-significant change of serum lipase and insulin levels among the case group in comparison with the control group.

Conclusion: Fluctuations in blood glucose level particularly hypoglycemia can be considered a risk of tramadol poisoning. Acute tramadol toxicity seems unlikely to cause acute pancreatitis, despite the high amylase level. This debate still requires further studies. Clinicians should remain alert for serial blood glucose monitoring in tramadol poisoning.
\end{abstract}

Key words: Tramadol, Glucose, Hypoglycemia, Pancreatitis, Amylase 


\section{INTRODUCTION}

Tramadol is a centrally acting synthetic analgesic agent with opioid and non-opioid properties (Fournier et al., 2015). It is used for moderate to severe pain relief due to its relatively lower risk of physical dependence and respiratory depression and better safety profile in comparison with other opiates (Ghamsari et al., 2016).

The mode of action of tramadol is not fully understood, but two acceptable complementary mechanisms are; binding to $\mu$ opioid receptors and inhibition of norepinephrine and serotonin reuptake (Mugunthan and Davoren, 2012; Beakley et al., 2015).

Tramadol is available, in both oral and parenteral pharmaceutical forms (Ghamsari et al., 2016). The drug is rapidly absorbed orally, a peak concentration is detected in 2-3 hours. It has extensive tissue distribution. Its volume of distribution is about $3 \mathrm{~L} / \mathrm{kg}$. Thirty per cent of tramadol is excreted unchanged renally, while the remaining is metabolized in liver by $\mathrm{N}$ - and $\mathrm{O}-$ demethylation and catalyzed by cytochrome P450 (CYP2D6) to many metabolites. The active metabolite (M1) shows higher affinity for the $\mu$ opioid receptors and has twice the potency of the parent drug (Taghaddosinejad et al., 2011; Samaka et al., 2012; Sweileh et al., 2016).

In recent years, tramadol abuse and overdose and even suicide commitments and related deaths have been dramatically increasing and becoming one of the most common causes of poisoning admissions to emergency departments in Egypt and worldwide (Mohamed et al., 2015; Ghamsari et al., 2016; Ibrahim et al., 2016).
Tramadol overdose clinical manifestations usually range between nausea, vomiting, dizziness to respiratory depression, pulmonary edema, cardiovascular system (CVS) collapse, decreased level of consciousness or seizure (Gair and Kent, 2010; Ryan and Isbistera, 2015). Recently, several spontaneous reports have raised concerns linking tramadol use with an increased risk of another potentially fatal complication; hypoglycemia (Fournier et al., 2015). This association has been limited to case reports and case series and has not been given sufficient attention (Nasouhi et al., 2015; Nelson and Juurlink, 2015).

The objective of this study is to investigate the effect of tramadol poisoning on blood glucose level and whether or not this effect is associated with tramadol-induced acute pancreatitis in patients admitted to Poison Control Center of Ain Shams University Hospitals (PCC-ASUH).

\section{PATIENTS \& METHODS}

A prospective observational study was conducted in PCC-ASUH during the period between November 2014 and August 2016. Adult patients $(\geq 18$ year-old) with acute tramadol only toxicity based upon history and clinical presentation were selected, in addition to healthy volunteers of matched age and gender who served as a control group. Exclusion criteria included any patient with history of neurological, cardiovascular, pulmonary, liver, renal or pancreatic and other endocrinal diseases. Exclusion criteria included also diabetics, pregnants and any patient with co-ingestion of other opioids, cannabis, anti-psychotic, antiepileptic, 
hypoglycemic (anti-diabetics, beta blockers, etc.) or hyperglycemic drugs (calcium channel blockers, corticosteroids, etc.). An informed written consent was taken from each patient or his/her guardian, in addition, to head of PCC and Ethical Committee approval.

Methods:

All patients were subjected to complete medical history, physical examination and biochemical laboratory investigations.

Data collection:

Descriptive variables: age, gender, delay time, amount taken, route of intake and manner of toxicity; abuse overdose, suicidal, accidental (Iatrogenic).

Clinical variables:

Vital signs: heart rate, systolic blood pressure, diastolic blood pressure, respiratory rate, temperature.

General manifestations: sweating, cyanosis, pallor, cold clammy skin.

Neurological examination: pupil size and reactivity, seizures, level of consciousness assessed by Reed's classification according to Karmakar (2015).

Pulmonary examination: respiratory distress, apnea, acute pulmonary edema.

Gastro-intestinal manifestations: nausea, vomiting, constipation, diarrhea, abdominal pain.

Laboratory variables:

Serum electrolytes levels: sodium $\left(\mathrm{Na}^{+}\right)$and potassium $\left(\mathrm{K}^{+}\right)$were determined by flame absorption photometer Jenway-PFP7 (Bibby Scientific Limited OSA, UK) (Rothrock et al., 1997).

Kidney function tests: serum creatinine and urea were measured by colorimetric method (Lawrence and Robert, 1993).

Liver enzymes: aspartate aminotransferase (AST), alanine aminotransferase (ALT) were determined by colorimetric method (Suber, 1994).

Glycosylated hemoglobin (HbA1c): measured according to Sacks (2005).

Arterial blood gases: samples analyzed in the Blood Gas Analyzer ABL 800-Basic. The pH, $\mathrm{PO}_{2}, \mathrm{PCO}_{2}$, and $\mathrm{HCO}_{3}$ values were recorded (Burnett et al., 1995).

Random blood glucose level: done by colorimetric method (Kaplan, 1984).

Pancreatic enzymes test: serum amylase and serum lipase were determined by enzymatic colorimetric method (Ziegenhorn, 1979; Junge, 1989).

Serum insulin level: measured according to Keilacker et al. (1987).

Random blood glucose level was obtained twice; on admission before any medication is given and 24 hours later (on the second day) for reevaluation and to pick up probable delayed toxic effects. As regards the controls, they were sampled once. Hypoglycemia was considered at glucose level $<70 \mathrm{mg} / \mathrm{dL}$, while hyperglycemia was considered at glucose level >140 mg/dL (normal glucose level ranges from 70 to less than $140 \mathrm{mg} / \mathrm{dL}$ ) according to Frank et al. (2012). All patients received supportive medical treatment. This followed an approved standard protocol, which was dictated by the patient's clinical condition (Boyer et al., 2012).

Statistical Analysis: The statistical analysis was performed using a 
standard SPSS (Statistical Package for Social Science) software package, version 17 (Chicago, IL), using power and sample size. Data were expressed as mean \pm standard deviation (SD) and as numbers (\%) for categorical variables. Student's $t$-test was used to analyze the parametric data, discrete variables were analyzed using chisquare test $(\chi 2)$. $\mathrm{P}<0.05$ was considered statistically significant (Taylor, 1990).

\section{RESULTS}

Twenty nine patients, 25 males $(86.2 \%)$ and 4 females $(13.79 \%)$ met inclusion criteria. Mean age was (31.34 \pm 8.75 years). Patients of tramadol abuse intake were $(26 ; 89.65 \%)$ while those with suicidal intake were (3; $10.34 \%$ ) and none showed accidental intake. Oral (tablets) route of intake was in $(23 ; 79.31 \%)$ and injection route was in $(6 ; 20.68 \%)$. The exact amount of tramadol intake could not be identified. The average delay time was (3.7 \pm 2.6 hours) ranging between (1-12 hours).

Table (1): shows that there was a significant decrease of systolic and diastolic blood pressure and respiratory rate in tramadol toxicity patients in comparison to the control. While, there was non-significant change between tramadol toxicity patients and the control group as regard the heart rate and temperature.

Table (2): shows the average values of admission day clinical data of tramadol toxicity patients in which sweating was manifested in 10 patients $(34.48 \%)$, cold clammy skin in 6 patients $(20.68 \%)$. Eleven patients $(37.93 \%)$ showed reactive miosis and 4 patients $(6.89 \%)$ showed mydriasis. Most patients $(16 ; 55.17 \%)$ presented with coma II and 7 patients $(24.13 \%)$ experienced seizure. Cyanosis was obvious in 3 patients $(10.34 \%)$, seven patients $(24.13 \%)$ were with respiratory distress, while 2 patients $(6.89 \%)$ had acute pulmonary edema and 2 patients $(6.89 \%)$ were with apnea. Nine patients $(31.03 \%)$ needed ICU admission and mechanical ventilation. Regarding gastrointestinal manifestations; nausea and vomiting were the most common symptoms (27 patients; 93.1\%) followed by abdominal pain (25 patients; $86.2 \%$ ).

Table (3): reveals that serum levels of $\mathrm{Na}+, \mathrm{k}+$, creatinine, urea, ALT, AST and HbAlc showed non-significant change between tramadol poisoned patients and the control group.

Table (4): shows that there was highly significant decrease of $\mathrm{pH}$ and $\mathrm{PO}_{2}$ and a highly significant increase of $\mathrm{PCO}_{2}$ in tramadol overdose patients as compared with the control group. Also, there was a significant decrease of $\mathrm{HCO}_{3}$ in tramadol overdose patients in comparison with the control group.

Table (5): reveals that there was non-significant change between tramadol poisoned patients and the control group regarding blood glucose level on admission day (first day). On the other hand, there was a significant decrease of glucose level on the second day as compared to the control, as well as, when compared with glucose level on the first day. The glucose level ranged between (50-213 $\mathrm{mg} / \mathrm{dL})$ on admission and on the second day the level ranged between $(50-131 \mathrm{mg} / \mathrm{dL})$.

Table (6): shows that there was a significant increase of percentage of cases with hypoglycemia $(48.27 \%)$ and a significant decrease of cases with hyperglycemia $(0 \%)$ on the second day as compared to the first day $(17.24 \%$ and $13.79 \%$ respectively). While, there 
was insignificant difference between first and second day regarding normoglycemia proportion of cases.

Table (7): shows a significant increase of serum amylase level and a

Table (1): Student's t-test Statistical Analysis of vital signs between tramadol poisoned patients (case group) and the control group.

\begin{tabular}{|l|c|c|c|c|}
\hline \multicolumn{1}{|c|}{ Groups } & $\begin{array}{c}\text { Control group } \\
\text { (No.29) } \\
\text { Mean } \pm \text { SD }\end{array}$ & $\begin{array}{c}\text { Case group } \\
\text { (No.29) } \\
\text { Mean } \pm \text { SD }\end{array}$ & t & P \\
\hline Heart rate (beat/minute) & $83.73 \pm 10.89$ & $82.34 \pm 16.39$ & 0.35 & $>0.05$ \\
\hline Systolic blood pressure (mmHg) & $118.36 \pm 9.71$ & $109.44+15.05^{*}$ & 2.49 & $<0.05$ \\
\hline Diastolic blood pressure (mmHg) & $77 \pm 7.11$ & $72.1+7.45^{*}$ & 2.28 & $<0.05$ \\
\hline Respiratory rate (breath/minute) & $16.26 \pm 2.53$ & $14.03 \pm 3.41^{*}$ & 2.58 & $<0.05$ \\
\hline Temperature 0C & $37.12 \pm 0.18$ & $37.03 \pm 0.14$ & 1.67 & $>0.05$ \\
\hline
\end{tabular}

t: comparison with control. $P>0.05$ non-significant difference. $* P<0.05$ significant difference. NO: Number. SD: standard deviation.

Table (2): Percentages of clinical manifestations in tramadol overdose patients on admission (case group; No. 29 patients).

\begin{tabular}{|l|l|}
\hline \multicolumn{1}{|c|}{ Clinical manifestations } & No. $(\%)$ \\
\hline Sweating & $10(34.48 \%)$ \\
\hline Cyanosis & $3(10.34 \%)$ \\
\hline Pallor & $0(0 \%)$ \\
\hline Cold clammy skin & $6(20.68 \%)$ \\
\hline \multicolumn{2}{|c|}{ Neurological manifestations } \\
\hline Bilateral Miosis & $11(37.93 \%)$ \\
\hline Bilateral mydriasis & $2(6.89 \%)$ \\
\hline Conscious & $2(6.89 \%)$ \\
\hline Coma I & $4(13.79 \%)$ \\
\hline Coma II & $16(55.17 \%)$ \\
\hline Coma III & $4(13.79 \%)$ \\
\hline Coma IV & $3(10.34 \%)$ \\
\hline Seizure & $7(24.13 \%)$ \\
\hline \multicolumn{2}{|c|}{ Gespiratory manifestations } \\
\hline Distress & $7(24.13 \%)$ \\
\hline Pulmonary edema & $2(6.89 \%)$ \\
\hline Apnea & $2(6.89 \%)$ \\
\hline Mechanically ventilated & $9(31.03 \%)$ \\
\hline \multicolumn{2}{|c|}{ Gautestinal manifestations } \\
\hline Nausea and Vomiting & $27(93.1 \%)$ \\
\hline Diarrhea & $2(6.89 \%)$ \\
\hline Constipation & $0(0 \%)$ \\
\hline Abdominal pain & $25(86.2 \%)$ \\
\hline
\end{tabular}

No: Number. non-significant change of serum lipase level and insulin level among tramadol control group. poisoned patients as compared with the 
Table (3): Student's t-test Statistical Analysis of serum levels; sodium $\left(\mathrm{Na}^{+}\right)$, potassium $\left(\mathrm{K}^{+}\right)$, creatinine, urea, aspartate aminotransferase (AST), alanine aminotransferase (ALT) and glycosylated hemoglobin (HbA1c) between tramadol poisoned patients (case group) and the control group

\begin{tabular}{|l|c|c|c|c|}
\hline & $\begin{array}{c}\text { Control group } \\
\text { (No.29) } \\
\text { Mean } \pm \text { SD }\end{array}$ & $\begin{array}{c}\text { Case group } \\
\text { (No.29) } \\
\text { Mean } \pm \text { SD }\end{array}$ & t & P \\
\hline $\mathrm{Na}^{+}(\mathrm{mEq} / \mathrm{L})$ & $134.52 \pm 4.27$ & $133.03 \pm 4.81$ & 1.12 & $>0.05$ \\
\hline $\mathrm{K}^{+}(\mathrm{mEq} / \mathrm{L})$ & $3.62 \pm 0.46$ & $3.51 \pm 0.57$ & 0.69 & $>0.05$ \\
\hline $\mathrm{S}$. creatinine (mg/dL) & $1.17 \pm 0.15$ & $1.08 \pm 0.18$ & 1.82 & $>0.05$ \\
\hline Urea $(\mathrm{mg} / \mathrm{dL})$ & $32 \pm 5.24$ & $31.68 \pm 9.18$ & 0.14 & $>0.05$ \\
\hline AST (IU/L) & $28.31 \pm 4.28$ & $29.93 \pm 4.57$ & 1.24 & $>0.05$ \\
\hline ALT (IU/L) & $27.63 \pm 5.03$ & $29.41 \pm 4.18$ & 1.27 & $>0.05$ \\
\hline HbA1c (\%) & $5.42 \pm 0.34$ & $5.74 \pm 1.63$ & 1.63 & $>0.05$ \\
\hline
\end{tabular}

t: comparison with control. $P>0.05$ non -significant difference. $P<0.05$ significant difference. NO: Number. SD: standard deviation.

Table (4): Student's t-test Statistical Analysis of arterial blood gas (ABG) values: $\mathrm{pH}$, partial pressure of oxygen $\left(\mathrm{PO}_{2}\right)$, partial pressure of carbon dioxide $\left(\mathrm{PCO}_{2}\right)$ and bicarbonate $\left(\mathrm{HCO}_{3}\right)$ between tramadol poisoned patients (case group) and the control group.

\begin{tabular}{|c|c|c|c|c|}
\hline Groups & $\begin{array}{c}\text { Control group } \\
\text { (No.29) } \\
\text { Mean } \pm \text { SD }\end{array}$ & $\begin{array}{c}\text { Case group } \\
\text { (No.29) } \\
\text { Mean } \pm \text { SD }\end{array}$ & $\mathrm{t}$ & $\mathrm{P}$ \\
\hline $\mathrm{pH}$ & $7.39 \pm 0.03$ & $7.23 \pm 0.12^{* *}$ & 6.82 & $<0.001$ \\
\hline $\mathrm{PO}_{2}(\mathrm{mmHg})$ & $88.42 \pm 6.74$ & $59.65 \pm 18.25 * *$ & 7.72 & $<0.001$ \\
\hline $\mathrm{PCO}_{2}(\mathrm{mmHg})$ & $38.94 \pm 3.37$ & $49.48 \pm 13.22^{* *}$ & 4.09 & $<0.001$ \\
\hline $\mathrm{HCO}_{3}(\mathrm{mEq} / \mathrm{L})$ & $24.73 \pm 2.68$ & $20.84 \pm 5.32 *$ & 3.34 & $<0.05$ \\
\hline
\end{tabular}

t: comparison with control. $\mathbf{P}>0.05$ non-significant difference. $* \mathbf{P}<0.05$ significant difference. $* * \mathbf{P}<0.001$ highly significant difference. NO: Number. SD: standard deviation

Table (5): Student's t-test Statistical Analysis of random blood glucose level on admission day (first day) and on the second day among tramadol poisoned patients (case group) and the control group

\begin{tabular}{|c|c|c|c|}
\hline \multirow[b]{2}{*}{ Parameter } & \multirow{2}{*}{$\begin{array}{l}\text { Control group } \\
\text { (No.29) } \\
\text { Mean } \pm \text { SD }\end{array}$} & \multicolumn{2}{|c|}{$\begin{array}{c}\text { Case group } \\
\text { (No.29) }\end{array}$} \\
\hline & & $\begin{array}{c}\text { First day } \\
\text { Mean } \pm \text { SD }\end{array}$ & $\begin{array}{l}\text { Second day } \\
\text { Mean } \pm \text { SD }\end{array}$ \\
\hline $\begin{array}{l}\text { Random blood glucose level } \\
\text { (mg/dL) } \\
\qquad \begin{array}{lll}\text { t1 } & \text { P1 } \\
\text { t2 } & \text { P2 }\end{array}\end{array}$ & $91.94 \pm 12.69$ & $\begin{array}{c}102.10 \pm 41.34 \\
1.22>0.05\end{array}$ & $\begin{array}{l}80.75 \pm 22.26 * \# \\
2.21<0.05 \\
2.44<0.05\end{array}$ \\
\hline
\end{tabular}

t1 P1: comparison with control. t2 P2: comparison with first day. $P>0.05$ nonsignificant difference. $\mathrm{P}<0.05$ significant difference. *: significant difference with control.

\#: significant difference with first day. NO: Number. SD: standard deviation. 
Table (6): Chi-square test $(\chi 2)$ comparing between admission day (first day) and the second day regarding hypoglycemia, normoglycemia and hyperglycemia among tramadol poisoned patients (case group; No. 29 patients)

\begin{tabular}{|l|c|c|c|}
\hline \multicolumn{1}{|c|}{ Days } & $\begin{array}{c}\text { First day } \\
\text { No. }(\%)\end{array}$ & $\begin{array}{c}\text { Second day } \\
\text { No. }(\%)\end{array}$ & $\mathrm{P}$ \\
\hline $\begin{array}{l}\text { Hypoglycemia } \\
(\text { BGL }<70 \mathrm{mg} / \mathrm{dL})\end{array}$ & $5(17.24 \%)$ & $14(48.27 \%)$ & $<0.05$ \\
\hline $\begin{array}{l}\text { Normoglycemia } \\
(\text { BGL: } 70-<140 \mathrm{mg} / \mathrm{dL})\end{array}$ & $20(68.96 \%)$ & $15(51.72 \%)$ & $>0.05$ \\
\hline $\begin{array}{l}\text { Hyperglycemia } \\
(\text { BGL }>140 \mathrm{mg} / \mathrm{dL})\end{array}$ & $4(13.79 \%)$ & $0(0 \%)$ & $<0.05$ \\
\hline
\end{tabular}

BGL: blood glucose level. $P>0.05$ non-significant difference. $P<0.05$ significant Difference. NO: Number.

Table (7): Student's t-test Statistical Analysis of serum levels of; amylase, lipase and insulin between tramadol poisoned patients (case group) and the control group.

\begin{tabular}{|c|c|c|c|c|}
\hline Parameters & $\begin{array}{l}\text { Control group } \\
\text { (No.29) } \\
\text { Mean } \pm \text { SD }\end{array}$ & $\begin{array}{c}\text { Case group } \\
\text { (No.29) } \\
\text { Mean } \pm \text { SD }\end{array}$ & $\mathrm{t}$ & $\mathrm{P}$ \\
\hline Amylase (IU/L) & $69.78 \pm 28.04$ & $189.10 \pm 148.24^{*}$ & 3.45 & $<0.05$ \\
\hline Lipase (IU/L) & $27.78 \pm 15.83$ & $25.89 \pm 11.74$ & 0.44 & $>0.05$ \\
\hline Insulin $(\mu \mathrm{IU} / \mathrm{mL})$ & $15.02 \pm 8.44$ & $13.61 \pm 7.29$ & 0.59 & $>0.05$ \\
\hline
\end{tabular}

t: comparison with control. $\mathbf{P}>0.05$ non -significant difference. $* \mathbf{P}<0.05$ significant difference. NO: Number. SD: standard deviation.

\section{DISCUSSION}

Tramadol overdose is one of the most frequent health and social problems in Egypt and worldwide (Mohamed et al., 2015; Ghamsari et al., 2016). In the last four years, tramadol abuse has become an increasingly alarming trend in the Egyptian community (Ibrahim et al., 2016). In this study the majority of patients were males $(86.2 \%)$ in the age group of (31.34 \pm 8.75 years) this is similar to previous studies (Shadnia et al., 2012; Hassanian-Moghaddam et al., 2013; Rahimi et al., 2014). Where tramadol overdose was considered as one of the most recent and frequent causes of drug poisoning, especially among young adult males who abuse it for pleasurable, psychoactive, sexual and endurance reasons (Mohamed et al., 2015; Nasouhi et al., 2015; Sweileh et al., 2016). Furthermore, the results in this study indicated that oral route is the most common route of exposure, which is similar with the findings of previous studies (Shadnia et al., 2008; Babalonis et al., 2013) probably due to cheap price and readily availability of tramadol tablets despite of it being scheduled (Ibrahim et al., 2016).

Chronic administration of tramadol in experimental studies demonstrated increased kidney and liver function tests (Atici et al., 2005). While, in this study due to acute onset of toxicity there was not significant change in kidney and liver function tests, serum $\mathrm{K}^{+}$or $\mathrm{Na}^{+}$levels in tramadol poisoned patients as compared with the control. This is in accordance with (Hassanian- 
Moghaddam et al., 2013; Rahimi et al., 2014). In contrast, Le Berre et al. (2007) reported tramadol induced hyponatremia which was described as a result of inappropriate anti-diuretic hormone secretion.

In the current study there was significant acidosis, hypoxemia, hypercapnia and bicarbonate decrease, as well as, significant decrease of respiratory rate and blood pressure in tramadol cases in comparison to the control levels. This could be attributed to tramadol-induced respiratory and CVS depression (Rahimi et al., 2014; Ryan and Isbister, 2015).

Regarding blood glucose level in this study, there was non-significant difference of admission (first day) blood glucose level as compared with the control, while there was significant decrease of blood glucose level on the second day as compared with the control as well as when compared with the first day level. Hypoglycemic patients in this study comprised $(17.24 \%)$ on first day and $(48.27 \%)$ on second day. Other previous studies reported two cases of tramadol-induced hypoglycemia; one in an 88-year-old woman without diabetes and the other in an 8-year-old girl with diabetes. In both cases, the hypoglycemia resolved spontaneously after discontinuation of tramadol (Grandvuillemin et al., 2006). Another case report from France (Taugourdeau et al., 2011) noticed severe hypoglycemia in two additional patients who were receiving oral tramadol intake. Hospitalization for hypoglycemia has been also reported in a woman with intentional tramadol overdose (Mugunthan and Davoren, 2012). Also, Fournier et al. (2015) noticed that tramadol use is associated with an increased risk of hospitalization for hypoglycemia. Although, hypoglycemia was uncommon (approximately 7 per 10000 per year of tramadol therapy).This was explained by Nelson and Juurlink (2015) in that the true rate is likely higher because hypoglycemia is commonly not reported in diabetics, and may not be recognized in non-diabetic patients. Thus, hypoglycemia was considered as a serious hazard of tramadol in diabetic and non-diabetic patients (JonvilleBera et al., 2010; Taugourdeau et al., 2011). In a recent study by Nasouhi et al. (2015) fourteen patients $(11 \%)$ experienced hypoglycemia in tramadol overdose patients. They found nonsignificant relation between the dose of tramadol and blood glucose level.

The risk of hypoglycemia with tramadol is not well described (Fournier et al., 2015). Tramadol is metabolized in the liver to its active metabolites. The active metabolite (M1) has more affinity (200 times) for the $\mu$ opioid receptors and also it has more inhibitory effect on biogenic amine reuptake than that of parent drug molecule (Rahimi et al., 2014; Sweileh et al., 2016). In this regard, genetic polymorphism in humans may affect the tramadol metabolism and its peak blood concentration resulting into a different frequency and onset of tramadol clinical presentations during therapeutic doses or intoxication (Nelson and Juurlink, 2015). Bourne et al. (2013) believe that tramadolinduced hypoglycemia may appear in 1-3 days. This explains the prevalence of hypoglycemia occurrence on the second day compared to the first day in the current work.

The underlying mechanisms of hypoglycemia induced by tramadol are unclear. The only weak opioid 
analgesic drug reported to cause hypoglycemia is propoxyphene (Taugourdeau et al., 2011). Tramadolinduced hypoglycemia is related to its pharmaco-dynamic properties. Tramadol mainly acts through two mechanisms; the activation of $\mu$ opioid receptors and the inhibition of central serotonin and norepinephrine reuptake (Bourne et al., 2013; Beakley et al., 2015). Tramadol activation of $\mu$ opioid receptors may increase the risk of hypoglycemia. In rats with streptozotocin-induced diabetes, a tramadol injection dose-dependent glucose-lowering effect was observed and this effect was blocked in rats pretreated with naloxone, suggesting a strong implication of the $\mu$ pathways in tramadol directly reducing hepatic gluconeogenesis and enhancing peripheral glucose utilization and glucose uptake into skeletal muscle via non-insulin-mediated mechanisms (Cheng et al., 2001). The same authors had also shown that $\mu$ opioid receptors stimulation lowered plasma glucose in normal and diabetic rats and that loperamide, another $\mu$ receptor agonist, exerted the same effect as tramadol (Tzeng et al., 2003). In a different animal model, tramadol-mediated stimulation of $\mu$ receptors in the cerebral cortex and hypothalamus appeared to increase insulin signaling, thereby increasing hepatic sensitivity to insulin without affecting hepatic glucose output directly (Choi et al., 2005).

In addition, serotonin pathways are also known to have complex effects on peripheral glucose homeostasis (ElMerahbi et al., 2015). In rat models of diabetes, serotonin induced $\beta$ endorphin release and stimulated muscle glucose utilization through the activation of $\mu$ opioid receptors by a mechanism, which is neither dose- nor insulin dependent (Chi et al., 2007). In addition, hypoglycemia associated with selective serotonin re-uptake inhibitors treatment has also been reported (Pollak et al., 2001; Biagetti and Corcoy, 2013). A supposed serotoninergic-mediated mechanism is substantiated by experimental data showing that serotonin can increase insulin concentration in mice (Yamada et al., 1989). Insulin serum level in this study showed non-significant difference between tramadol overdose patients and the control. This is in accordance with (Cheng et al., 2001; Choi et al., 2005; Bourne et al., 2013) who stated that tramadol did not affect insulin level but instead increased insulin sensitivity.

There is tendency of tramadolinduced hypoglycemia to occur in high risk patients such as; those who are elderly, diabetic and with renal and hepatic impairment (Bourne et al., 2013; Jolobe, 2015). This may account for the low number of cases in this work because some of the afromentioned patients were among the exclusion criteria.

Hyperglycemia, on the other hand, occurred in only four cases $(13.79 \%)$ on admission and all resolved spontaneously within 24 hours without further therapeutic requirement. Hyperglycemia was experienced in eight patients $(6.25 \%)$ of tramadol poisoning on admission day in a study by Nasouhi et al. (2015). In addition, Martins et al. (2010) detected significant increase in blood glucose concentrations in dogs receiving tramadol. Hyperglycemia is a common problem in hospitalized patients under stress conditions with or without a 
history of diabetes mellitus (Lazzeri et al., 2009; Sanaei-Zadeh et al., 2011). Higher doses and intoxications are more likely to be accompanied by hyperglycemia. The major causes include increased release of stress hormones and pro-inflammatory cytokines. In addition to iatrogenic factors (administration of steroids, catecholamines and excess dextrose therapy) and underlying patients disease states (Sabzghabaee et al., 2011).

Acute pancreatitis can cause hypoglycemia or hyperglycemia together with ketoacidosis (Agarwal and Pitchumoni, 1993). Measurement of amylase and lipase is usually to confirm or exclude acute pancreatitis (Tuennemann et al., 2014; Muniraj et al., 2015). In this study amylase level was significantly increased in tramadol overdose cases in comparison with the control while there was nonsignificant difference regarding the lipase level. A similar case report of a woman with suicidal intake of tramadol who had elevated serum amylase was studied by (El-Hussuna et al., 2010).

The commonest cause of hyperamylasemia is acute pancreatitis; however, there is need to consider nonpancreatic causes of hyperamylasemia such as in patients with shock, trauma, hypoxemia, kidney damage, and acute liver failure especially when there is no elevation of lipase level (considered to be more specific than amylase) and there is absence of obvious clinical picture to support the diagnosis (Slack et al., 2010; Muniraj et al., 2015; Liu et al., 2016) which is similar to this study.

El-Hussuna et al. (2010) believe that high serum total amylase levels may also occur in patients with acidosis. It has been reported that acute hypoxemia may alone or in combination with other factors raise serum total amylase level possibly through ischemic injury to the pancreas or salivary glands. Accordingly, tissue hypoxia produces hyper-permeability of cell membranes, allowing intracellular amylase to leak out, resulting in high serum total amylase levels. In the current study there was significant mixed respiratory and metabolic acidosis together with significant hypoxemia in tramadol poisoned patients, thus, the high level of serum total amylase was most likely due to hypoxemia and acidosis rather than acute pancreatitis induced by tramadol toxicity.

Another explanation of hyperamylasemia in this study is suggested by (Benyamin et al., 2008) who noticed that opioids in general can cause hyperamylasemia in the absence of pancreatic or salivary gland disease, which might be due to spasm of the sphincter of Oddi via micro $\mu$ opioid receptors on pancreas.

Although, Shah et al. (2010) stated that in appropriate clinical setting, the diagnosis of acute pancreatitis should be entertained even with normal serum amylase and lipase levels. Yet, Pancreatitis is not mentioned as a side effect or a sign of tramadol toxicity (El-Hussuna et al., 2010) and this enzyme elevation usually requires ultrasonic and CT scan verification of pancreatitis. Also, pancreatic amylase and the salivary amylase are two specific amylase iso-enzymes. Pancreatic amylase has a better sensitivity and specificity than total serum amylase (Lippi et al., 2012; Muniraj et al., 2015) which will be 
recommended for laboratory monitoring in the future.

In another poison study, elevated serum level of amylase per se was found to be a valuable early predictor of mortality in patients with acute paraquat poisoning (Liu et al., 2016).

In summary: tramadol induced hypoglycemia in $17.24 \%$ of patients and hyperglycemia in $13.79 \%$ of patients on admission day. While, on the second day, tramadol induced only hypoglycemia in $48.27 \%$. These changes were associated with hyperamylasemia without obvious clinical evidence of acute pancreatitis. Thus, fluctuations in blood glucose level particularly hypoglycemia can be considered a risk of tramadol overdose. Further experimental and clinical studies on tramadol-induced hypoglycemia and possible acute pancreatitis are warranted. It is suggested to monitor pancreatic isoamylase level and to perform imaging procedures in cases of tramadol poisoning with hyperamylasemia for better confirmation or exclusion of acute subclinical pancreatitis. Serial blood glucose level monitoring in patients with tramadol-overdose is recommended for early recognition of hypoglycemia and its timely management.

\section{REFRENCES}

Agarwal, N. and Pitchumoni, C. (1993): Acute pancreatitis: a multisystem disease. Gastroenterologist; 1(2): 115-128.

Atici, S.; Cinel, I.; Cinel, L.; et al., (2005): Liver and $\mathrm{k}$ idney toxicity in chronic use of opioids: An experimental long term treatment model. J Biosci; 30: 245252.

Babalonis, S.; Lofwall, M.; Nuzzo, P.; et al., (2013): Abuse liability and reinforcing efficacy of oral tramadol in humans. Drug Alcohol Depend; 129(1-2): 116-124.

Beakley, B.; Kaye, A. and Kaye, A. (2015): Tramadol, pharmacology, side effects, and serotonin syndrome: A review. Pain physician; 18(4): 395-400.

Benyamin, R.; Trescot, A.; Datta, S.; et al., (2008): Opioid complications and side effects. Pain Physician: Opioid Special Issue; 11: S105-S120.

Biagetti, B. and Corcoy, R. (2013): Hypoglycemia associated with fluoxetine treatment in a patient with type 1 diabetes. World J Clin Cases; 1 (5): 169-171.

Bourne, C.; Gouraud, A.; Daveluy, A.; et al., (2013): Tramadol and hypoglycaemia: comparison with other step 2 analgesic drugs. Br J Clin Pharmacol; 75(4): 1063-1067.

Boyer, E. (2012): Management of opioid analgesic overdose. N Engl J Med; 367 (2): 146-155.

Burnett, R.; Covington, A.; FoghAnderson, N.; et al., (1995): Approved FCC recommendations on whole blood sampling, transport and storage for simultaneous determination of $\mathrm{pH}$ blood gases and electrolytes. Eur J Chem Clin Biochem; 33: 247-253.

Cheng, J.; Liu, I.; Chi, T.; et al., (2001): Plasma glucose-lowering effect of tramadol in streptozotocin-induced diabetic rats. Diabetes; 50(12): 2815-2821.

Chi, T.; Ho, Y.; Chen, W.; et al., (2007): Serotonin enhances betaendorphin secretion to lower 
plasma glucose in streptozotocininduced diabetic rats. Life Sci; 80: 1832-1838.

Choi, S.; Jang, J. and Park, S. (2005): Tramadol enhances hepatic insulin sensitivity via enhancing insulin signaling cascade in the cerebral cortex and hypothalamus of $90 \%$ pancreatectomized rats. Brain Res Bull; 67(1-2): 77-86.

El-Hussuna, A.; Arnesen, R. and Rosenberg, J. (2010): Tramadol poisoning with hyperamylasemia. BMJ Case Reports; 10(3): 1-3.

El-Merahbi, R.; Löffler, M.; Mayer, A.; et al., (2015): The roles of peripheral serotonin in metabolic homeostasis. FEBS Lett; 589(15): 1728-1734.

Fournier, J.; Azoulay, L.; Yin, H.; et al., (2015): Tramadol use and the risk of hospitalization for hypoglycemia in patients with noncancer pain. JAMA Intern Med; 175(2): 186-193.

Frank, E.; Shubha, M. and D'Souza, C. (2012): Blood glucose determination: plasma or serum? J Clin Lab Anal; 26(5): 317-320.

Gair, R. and Kent, D. (2010): Tramadol toxicity and treatment. Toxic Update Newsletter; 6(1): 14.

Ghamsari, A.; Dadpour, B. and Najari, F. (2016): Frequency of Electrocardiographic abnormalities in tramadol poisoned patients; a brief report. Emerg (Tehran). Summer; 4(3): 151-154.

Grandvuillemin, A.; Jolimoy, G.; Authier, F.; et al., (2006): Tramadol-induced hypoglycemia: 2 cases. Presse Med; 35(12, pt 1): 1842-1844.

Hassanian-Moghaddam,

H.;

Farajidana, H.; Sarjami, S.; et al., (2013): Tramadol-induced apnea. Am J Emerg Med; 31: 2631.

Ibrahim, S.; Ali, M.; Gouda, A.; et al., (2016): Association between the severity of tramadol toxicity and some CYP2D6 allelic variants in Egyptian tramadol intoxicated patients. Emerg Med; 6: 303.

Jolobe, O. (2015): Tramadol-related hypoglycaemia and tramadolinduced anorexia. Br J Hosp Med; 76(4): 249.

Jonville-Bera, A.; Marie, A.; Magba, D.; et al., (2010): Tramadolinduced hypoglycemia in a diabetic patient. Therapie; 65: 499-500.

Junge, W. (1989): Alpha amylase. Colorimetric test. Clin Biochem; 22: 109.

Kaplan, L. (1984): Glucose. In: Louis S (ed.). Clinical Chemistry, Mosby Co. Toronto; PP: 1032-1036.

Karmakar, R. (2015): Reed's classification of un-consciousness. In: Forensic Medicine and Toxicology: Theory, Oral \& Practical. Chapter 4: $5^{\text {th }}$ edition. Bimal Kumar Academic Publishers, India, P: 73.

Keilacker, H.; Besch, W.; Woltanski, K.; et al., (1987): Measurement of insulin in human sera using a new RIA kit.2. Determination of free and total insulin-correlations to insulin antibody levels. Exp Clin Endocrinol. 90(3): 271-277.

Lawrence, M. and Robert, H. (1993): Methods of determination of blood urea nitrogen, urea and serum creatinine. In: Tietz Textbook of Clinical Chemistry, 2nd edition, WB Saunders Company, London; PP: 621.

Lazzeri, C.; Tarquini, R.; Giunta, F.; et al., (2009): Glucose 
dysmetabolism and prognosis in critical illness. Intern Emerg Med. 4(2): 147-156.

Le Berre, J.; Desramé, J.; Lecoules, S.; et al., (2007): Hyponatremia due to tramadol. Rev Med Interne; 28: 888-889.

Lippi, G.; Valentino, M. and Cervellin, G. (2012): Laboratory diagnosis of acute pancreatitis: in search of the Holy Grail. Crit Rev Clin Lab Sci; 49(1): 18-31.

Liu, S.; Wang, Q.; Zhou, R.; et al., (2016): Hyperamylasemia as an early predictor of mortality in patients with acute paraquat poisoning. Med Sci Monit; 22: 1342-1348.

Martins, T.; Kahvegian, M.; NoelMorgan, J.; et al., (2010): Comparison of the effects of tramadol, codeine and ketoprofen alone or in combination on postoperative pain and on concentrations of blood glucose, serum cortisol and serum interleukin-6 in dogs undergoing maxillectomy or mandibulectomy. Am J Vet Res; 71: 1019-1026.

Mohamed, N.; El-Hamrawy, L.; Shalaby, A.; et al., (2015): An epidemiological study of tramadol $\mathrm{HCl}$ dependence in an outpatient addiction clinic at Heliopolis Psychiatric Hospital. Menoufia Medical Journal; 28(2): 591-596.

Mugunthan, N. and Davoren, $P$. (2012): Danger of hypoglycemia due to acute tramadol poisoning Endocr Pract; 18(6): e151-e152.

Muniraj, T.; Pitchumoni, C. and Dang, S. (2015): Pancreatitis or not? - Elevated lipase and amylase in ICU patients. Journal of Critical Care; 30: 1370-1375.
Nasouhi, S.; Talaie, H.; Pajoumand, A.; et al., (2015): Hypo- and hyperglycemia among tramadol overdose patients in Loghman Hakim Hospital, Tehran, Iran Pak J Pharm Sci; 28(6): 1959-1963.

Nelson, L. and Juurlink, D. (2015): Tramadol and hypoglycemia one more thing to worry about. JAMA Internal Medicine. 175(2): 194195.

Pollak, P.; Mukherjee, S. and Fraser, A. (2001): Sertraline-induced hypoglycemia. Ann Pharmacother; 35: 1371-1374.

Rahimi, H.; Soltaninejad, K. and Shadnia, S. (2014): Acute tramadol poisoning and its clinical and laboratory findings. J Res Med Sci; 19(9): 855-859.

Rothrock, S.; Green, S.; McArthur, C.; et al., (1997): Detection of electrolyte abnormalities

in children presenting to the emergency department: a multicenter, prospective analysis. Detection of electrolyte a bnormalities in children observational national study investigators; 4(11): 1025-1031.

Ryan, N. and Isbister, G. (2015): Tramadol overdose causes seizures and respiratory depression but serotonin toxicity appears unlikely. Clinical Toxicology; 53(6): 545550.

Sabzghabaee, A.; Eizadi-Mood, N.; Gheshlaghi, F.; et al., (2011): Is there a relationship between admission blood glucose level following acute poisoning and clinical outcome? Arch Med Sci; 7(1): 81-86.

Sacks, D. (2005): Global harmonization of hemoglobinA1c. 
Clinical Chemistry. 51(4): 681683.

Samaka, R.; Girgis, N. and Shams, T. (2012): Acute toxicity and dependence of tramadol in albino rats: Relationship of Nestin and Notch 1 as stem cell markers. J Am Sc; 8(6): 313-327.

Sanaei-Zadeh, H.; Esfeh, S.; Zamani, N.; et al., (2011): Hyperglycemia is a strong prognostic factor of lethality in methanol poisoning. J Med Toxicol; 7: (3): 189-194.

Shadnia, S.; Soltaninejad, K.; Heydari, K.; et al., (2008): Tramadol intoxication: A review of 114 cases. Hum Exp Toxicol; 27: 201-205.

Shadnia, S.; Brent, J.; MousaviFatemi, K.; et al., (2012): Recurrent seizures in tramadol intoxication: Implications for therapy based on 100 patients. Basic Clin Pharmacol Toxicol; 111: 133-136.

Shah, A.; Eddi, R.; Kothari, S.; et al., (2010): Acute pancreatitis with normal serum lipase: a case series. JOP; 11(4): 369-372.

Slack, S.; Abbey, I. and Smith, D. (2010): Abdominal pain and hyperamylasaemia-not always pancreatitis. BMJ Case Rep; 10(2): 1-3.

Suber, R. (1994): Clinical pathology methods for toxicology. In: Hayes AW (ed.). Principles and Methods of Toxicology. $3^{\text {rd }}$ ed., Raven Press, New York; PP: 476-496.
Sweileh, W.; Shraim, N.; Zyoud, S.; et al., (2016): Worldwide research productivity on tramadol: a bibliometric analysis. Springerplus; 5(1): 1108 .

Taghaddosinejad, F.; Mehrpour, O.; Afshari, R.; et al., (2011): Factors related to seizure in tramadol poisoning and its blood concentration. J Med Toxicol; 7(3): 183-188.

Taugourdeau, S.; Chiche, L.; Rouby, F.; et al., (2011): Severe hypoglycemia induced by tramadol: two new cases of an unlisted side effect. Rev Med Interne; 32: 703705.

Taylor, J. (1990): Statistical technique for data analysis. $2^{\text {nd }}$ ed., Lewis Pub. Inc., USA, PP: 25-30.

Tuennemann, J.; Mössner, J. and Beer, S. (2014): Acute pancreatitis: guideline-based diagnosis and treatment. Internist (Berl); 55(9): 1045-1056.

Tzeng, T.; Liu, I.; Lai, T.; et al., (2003): Loperamide increases glucose utilization in streptozotocin-induced diabetic rats. Clin Exp Pharmacol Physiol; 30: 734-738.

Yamada, J.; Sugimoto, Y.; Kimura, I.; et al., (1989): Serotonininduced hypoglycemia and increased serum insulin levels in mice. Life Sci; 45: 1931-1936.

Ziegenhorn, J. (1979): Methods of determination of lipase. Clin Chem; 25: 1067. 


\section{الملخص العربى}

\section{هل تتسبب السمية الحادة بالتر امادول فى نقصان مستوى الجلوكوز بالام

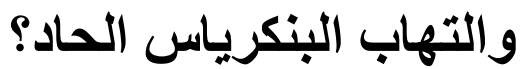

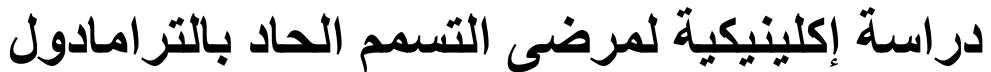 \\ إجلال حسن العوضي - هند محمد الهلالي الهري \\ قسم الطب الشر عي و السموم الإكلينيكية

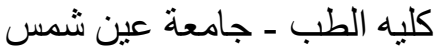

التر امادول مسكن اصطناعي للألم ويعمل مركزياً. وحديثاً، أصبحت الجرعة الزائدة من التر امادول أحد

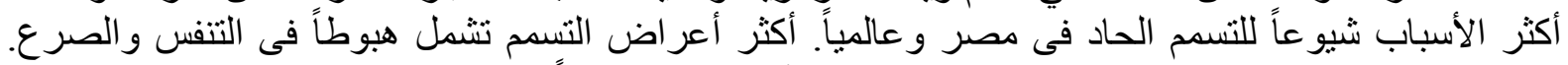

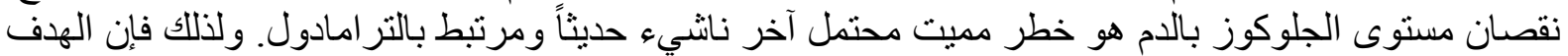

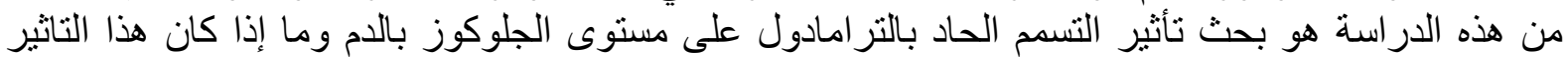

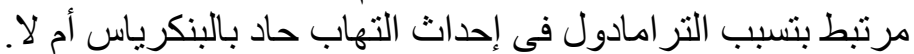

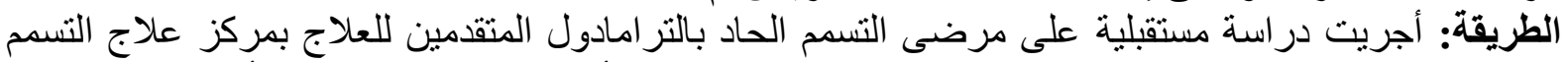

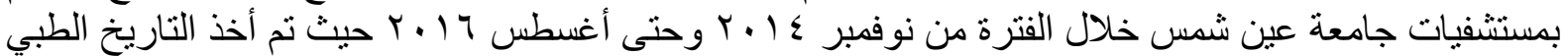
و الفحص البدني والفحوصات المخبرية الروتينية الحيوية لهح. بالإضافة لمستوى الأمايليز واللايبيز والإنسولين

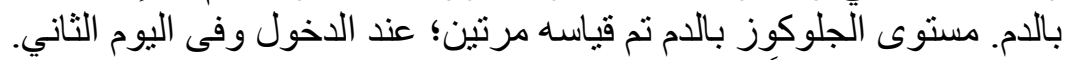

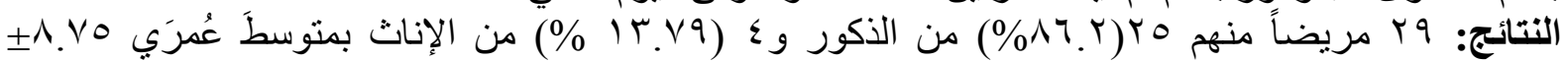

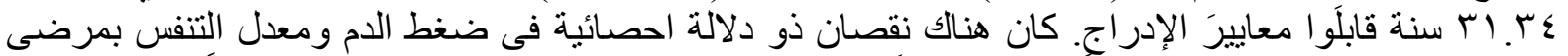

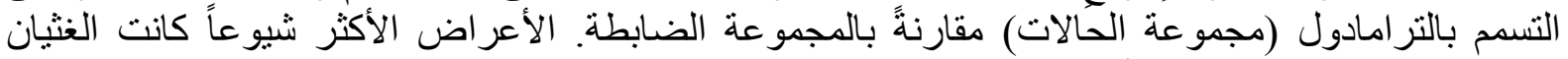

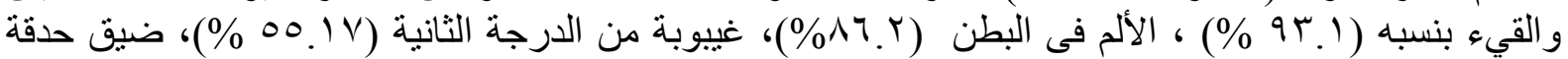
العين (r.q.

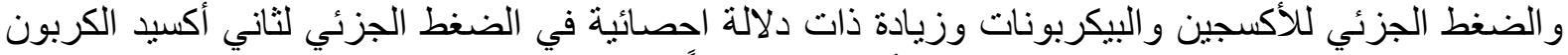

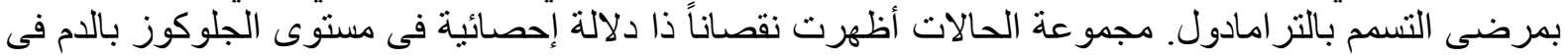

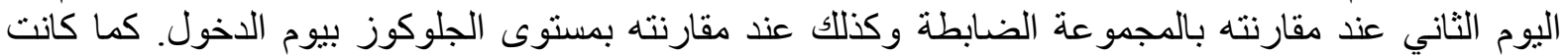

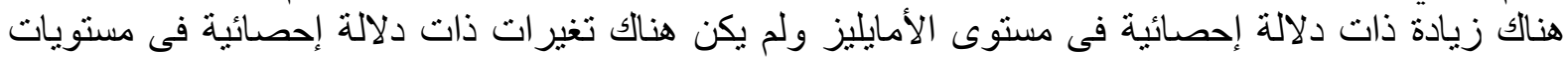

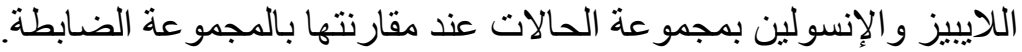

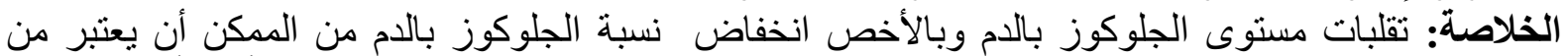

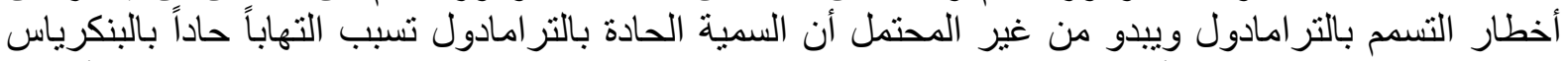

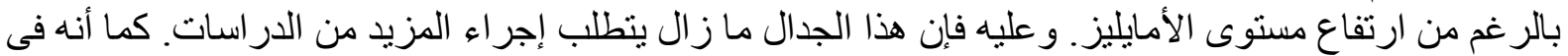
حالة التسمم بالتر امادول يجب بقاء الأطباء منتبهين لقياس مستوي الجلوكوز بشكل منتظم. 